\title{
A WALT WHITMAN MANUSCRIPT
}

\author{
By Oral Sumner Coad
}

Dr. Coad's excursion into the poetry of Walt Wbitman is directly in line with bis continued interest in American literature from graduate school days to the present. In $19 I 7$ be publisbed a life of the early nineteentb century playwright, William Dunlap. A few years later be edited the Autobiography of Benjamin Franklin. In collaboration with Edwin Mims, $\mathcal{F r}$., be wrote in 1929 The American Stage. Witbin the last few montbs be bas completed a volume of unpublisbed plays of William Dunlap.

AST winter the Rutgers Library received a ragged sheet of paper, measuring $8 \times 93 / 4$ inches, containing a hand-written version of "Hush'd be the Camps To-day," one of the poems in which Walt Whitman lamented the death of Lincoln. That the writing is Whitman's own there can be no doubt. The history of the manuscript is alone sufficient evidence. It was presented to the Library by the Reverend John H. S. Putnam of the Class of I9I3, to whom it was given by Mr. B. Clifford Kline, whose wife, Neltje Eckler, was the daughter of Peter Eckler of New York, printer of some of Whitman's poetry. ${ }^{1}$ The reverse of the sheet bears the inscription

Written by Walt Whitman I 866

P. Eckler

Moreover this testimony is confirmed beyond question by a comparison of the writing with photographic reproductions of the poet's penmanship in Emory Holloway's Whitman: An Interpretation in Narrative.

1 It seems altogether probable that Eckler printed Drum-Taps (1865), the volume in which this poem first appeared, and which was brought out minus any publisher's or printer's name. Mr. Kline has been so good as to let me see a manuscript letter which he owns, written by Whitman to Eckler on May 3, 1865, mentioning a remittance of $\$ 20$ on May ist and enclosing another of $\$ 14.85$ "as payment in full." It instructs Eckler to deliver certain sheets to A. Simpson at 8 Spruce Street. While the letter does not indicate what the payments were for, or what the sheets contained, I am convinced it refers to the printing of Drum-Taps. Whitman was not engaged in bringing out any other book in 1865 ; moreover I am informed by a local printer that the sums stated would, according to the rates of that period, just about pay for the printing, but not the binding, of the little book of seventy-two small pages. Trow's New York City Directory for 1865 lists Abraham Simpson, 8 Spruce Street, as a printer, and it is my guess that Whitman had engaged him to bind the sheets when they came from Eckler's press. 
There is every reason to believe that the poem was first worked out on the sheet of paper under discussion. Many words and phrases are canceled and alterations written in above them in such a way as to reveal the labors of composition. The first stanza, which, with the title, is reproduced below, appears to have taken shape with relatively little effort.

$\frac{\text { Hush'd be the camps [the land,] to-day. }}{{ }^{2}}$

I/ Hush'd be the camps, [the land,] to-day;

And, soldiers, let us drape our war-worn weapons [his own soul]

And each, with musing soul retire, to celebrate,

Our dear commander's death

The second stanza, however, gives evidence of having resisted most stubbornly before it was reduced to a form satisfactory to the poet. The final version is written on a slip of paper pasted over another slip that is in turn pasted over the original lines. Whitman used a good brand of paste that refused to yield to inexpert manipulation, but when Mr. Pierre Whitham of the Library staff applied his skill to the problem, the three pieces were separated without the slightest damage to the paper or the ink. It was then discovered that the author had made not three but four distinct attempts at this stanza, for on the reverse of the first superimposed slip was a penciled version differing materially from any of the others.

First version-on the original sheet

2 No more for him life's stormy conflict, [rapid varied] watch, the

No more the ${ }_{\wedge}$ toil, the ${ }_{\wedge}$ high command;

[(No more the age's sweetest, faithfulest heart;)]

for time's [hourly ceaseless]

No more [to] him [the varied, $]_{\wedge}$ mightiest,

[ceaseless]

dark events,

Charging like ${ }_{\wedge}$ clouds across the sky.

2 All passages between square brackets are deleted by a penstroke in the manuscript. 
Second version-in pencil on the reverse of the first slip

No more his days nor toils

No more that ${ }^{3}$ wisest, sweetest, bravest heart,

No more for him life's stormy battle

No more the [varied, $]_{\wedge}$ mighty [strange] events

Chasing each other like clouds across

the sky.

Third version-on the obverse of the first slip

2 No more for him life's stormy conflict

perplexing -no [orders clear across ${ }^{3}$ the din;

No more the toil, [the watch,] the ${ }_{\wedge}$ [high command;]

No more, [for him,] time's [mightiest] dark events,

Charging like ceaseless clouds across

the sky.

Fourth version-on the second slip

2/ No more for him life's stormy conflict;

Nor victory, nor defeat-No more time's

dark events,

Charging like ceaseless clouds across

the sky.

In the brief third stanza the manuscript shows no revision whatever.

3/ But sing, poet, in our name,

Sing of the love we bore him-because you,

dweller in camps, know it truly.

3 The reading of this word is uncertain. 


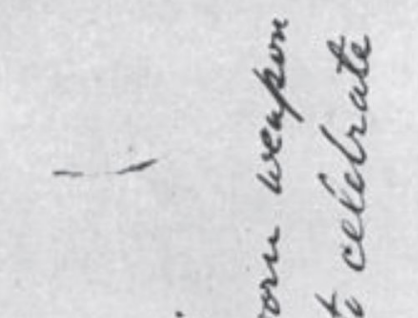

3) $\quad$ ह

a

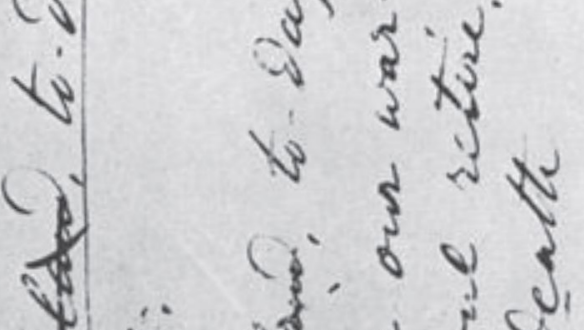

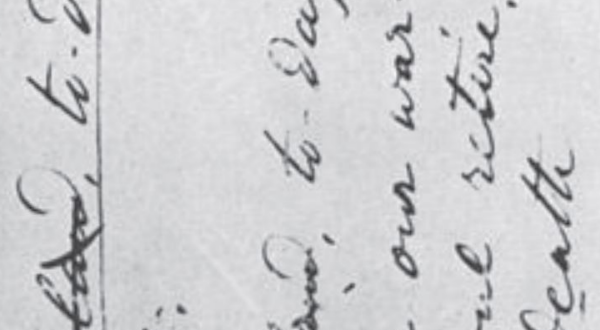

* कर अनक

*

c

से

as 23.

ris

तु से

C

$i$

2

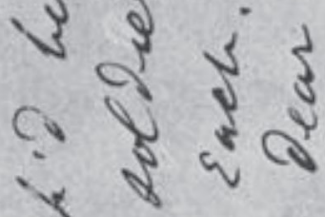

3

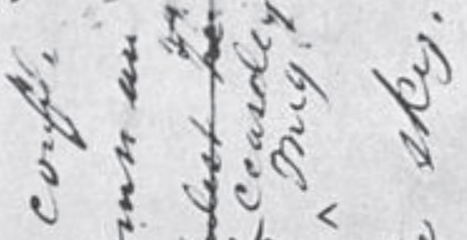

ఫ్

总 
But the final stanza required another major operation. The end of the sheet was cut off, except for a fragmentary line, and a new slip was pasted on, covering this vestigial remain. When this slip was removed by Mr. Whitham, these words were disclosed:

\title{
4 [Sing, for us where they lower the] coffin
}

there-drop in the grave one

The substituted lines read:

\author{
to the lower'd
4/ Sing, [as they lower the] coffin there; \\ Sing, with the shovel'd clods, [as they] \\ [that are] the grave-a verse,
}

For the heavy hearts of soldiers.

The intricate and elaborate reworking of this poem of a dozen lines is in keeping with Whitman's known method of composition. He was an endless reviser not only of his manuscripts but of the printed poems as they appeared in various editions. Further proof is to be found in the first published version (in DrumTaps, 1865) of "Hush'd be the Camps To-day," in which the second line of the fourth stanza reveals a reading not discovered in the manuscript: "Sing, with the shovel'd clods that fill the grave-a verse." This practice of Whitman's, so clearly apparent here, shows that he was less the language-intoxicated rhapsodist and more the laborious and even fussy craftsman than is sometimes supposed. In the present instance, at least, the changes were for the better. No one could doubt, for example, that the first line of the poem, which is also the title, gains by deletion of "the land," or that the fourth version of the second stanza is the most effective, partly because it is the simplest. It is illuminating to observe how he made this version by retaining the best lines and phrases from the preliminary attempts. Rejecting the comparatively flat "No more the toil," with which he experimented variously in the first three versions, he 
kept the fine line, "No more for him life's stormy conflict," which remains practically constant from the beginning. Then, apparently perceiving the implications of the key-word, "conflict," he added the logical sequel, "Nor victory, nor defeat." He realized that "time's dark events" was a good phrase, and he tried out every combination he could think of until it became "No more time's dark events"- the one wholly satisfying form. In discarding, as the last line of the stanza, "Chasing each other like clouds across the sky" for "Charging like ceaseless clouds across the sky" he again proved the soundness of his taste. And thus, after much effort, a powerful stanza was evolved. ${ }^{4}$

In an article, "The Evolution of Whitman as Artist," in American Literature for November, 1934, the late Killis Campbell wrote: "The average layman will laugh at the idea of accounting Whitman an artist. . . . But no student, I think, who really goes into Leaves of Grass, and certainly no one who acquaints himself with the genesis and growth of that poem, can escape the conclusion that Whitman, despite his many unevennesses and audacities, was both a deliberate and a painstaking artist." Surely the manuscript of "Hush'd be the Camps Today" tends to confirm Professor Campbell's thesis.

A final point: What did Whitman mean to imply when he wrote "April I 9 th I 865 " under his title? Possibly it indicates the actual date of composition, but more probably it indicates a lapse in the author's knowledge of historical fact. The poem is unmistakably a burial hymn, and when first published it bore the notation, "A. L. Buried April I9, I 865." In reality this was the date of the funeral services in Washington; the interment at Springfield did not take place until May 4 th. Whitman later realized his error, and when the poem was published in the I87I edition of Leaves of Grass it carried under the title the line, "(May 4, I865)." Because of this correction to square with the facts of Lincoln's obsequies, it seems highly unlikely that either date should be taken as the day of composition.

\footnotetext{
${ }^{4}$ Something Whitman may have salvaged from the discarded lumber of stanza two. The second version perhaps provided him with the basis for one of the memorable phrases of "When Lilacs Last in the Dooryard Bloom'd," in which he describes Lincoln as "the sweetest, wisest soul of all my days and lands."
} 